\title{
PENGARUH DISPLIN GURU TERHADAP PRODUKTIFITAS KERJA DI SMAN I SERUYAN TENGAH KABUPATEN SERUYAN
}

\author{
The influence of Teacher's Discipline on Work Productivity at SMAN I Seruyan Tengah Seruyan Regency
}

\section{Leda Almuqsith* \\ Ari Setiawan}

Universitas Muhammadiyah

Palangkaraya, Palangka Raya, Central

Kalimantan, Indonesia

email:

leda.almuqsith@umpalangkaraya.ac.id

\section{Kata Kunci:}

Disiplin

Produktifitas

Guru

Keywords:

Discipline

Productivity

Teacher

\section{Accepted}

June 2016

Published

Oktober 2016

\begin{abstract}
Abstrak
Tujuan yang hendak dicapai dari Penelitian ini adalah yaitu untuk mengetahui seberapa besar Displin Guru terhadap kualitas kerja di SMAN I Seruyan Tengah Kabupaten Seruyan. Metode yang digunakan dalam penelitian ini adalah metode kuantitatif dengan teknik observasi, dan kuisioner (angket). Sedangkan teknik analisis data yang digunakan dalam penilitian ini yaitu menggunakan anilisis korelasi product moment.

Berdasarkan hasil dari penilitian dan pembahasan, disiplin guru berpengaruh positif dan signifikan terhadap terhadap kualitas kerja guru SMAN I Seruyan Tengah kabupaten Seruyan,dimana indikator disiplin $(x)$ yang terdiri dari Tujuan dan kemampuan, Teladan pemimpin, Balas jasa, Keadilan, Waskat (pengawasan Melekat), Sanksi hukum, Ketegasan, Hubungan kemanusiaan berpengaruh positif dan signifikan terhadap terhadap kualitas kerja yang terdiri dari Tangibles (bukti fisik), Reliability (kehandalan), Responsiveness (ketanggapan), Assurance (jaminan dan kepastian), Empathy (empati). Berdasarkan hasil dari penilitian dan pembahasan, maka penulis memberikan saran kepada pegawai SMAN I Seruyan Tengah yaitu diharapkan adanya peningkatan pengawasan pimpinan dan perhatian kepada seluruh guru dalam melaksanakan tugasnya dan diharapkan adanya reward dan punishment dari pimpinan kepada guru agar tetap berkualitas dalam melaksanakan tugas.
\end{abstract}

\section{PENDAHULUAN}

Sumber daya manusia merupakan salah satu asset yang paling berharga yang dimiliki oleh suatu organisasi, karena manusialah yang merupakan satu-satunya sumber daya yang dapat menggerakkan sumber daya lainnya. Unsur sumber daya manusia merupakan faktor kunciyang harus dipertahan oleh suatu organisasi sejalan dengan tuntutan yang senantiasa dihadapi setiap organisasi untuk menjawab setiap tantangan yang ada. Oleh karena itu, dalam mempertahankan sumber daya manusia yang berkualitas merupakan faktor utama organisasi.

Untuk meningkatkan disiplin kerja guru, perlu adanya fasilitas kerja yang baik. Fasilitas kerja merupakan suatu bentuk pelayanan yang diberikan pemerintah 
dan sekolah terhadap pegawai agar menunjang kinerja dalam memenuhi kebutuhan pegawai, sehingga dapat meningkatkan kualitas kerja pegawai. Adanya fasilitas yang disediakan oleh pemerintah dan sekolah sangat mendukung pegawai dalam bekerja. Fasilitas kerja tersebut sebagai alat atau sarana dan prasarana untuk membantu pegawai agar lebih mudah dalam memberikan ilmu pendidikan kepada siswa dan siswinya sehingga dalam memberikan ilmu pendidikan lebih produktif. Dengan adanya fasilitas kerja, pegawai akan merasa nyaman dalam berkerja dan menimbulkan semangat kerja untuk mendapatkan hasil yang diharapkan oleh pemerintah. Fasilitas kerja dapat dilihat dari adanya fasilitas pendukung seperti : ruangan, printer, dan sebagainya.

Memberikan tempat kerja yang menyenangkan berarti pula menimbulkan perasaan yang nyaman dalam bekerja sehingga dengan cara demikian dapat mengurangi dari pemborosan waktu dan biaya. Dengan demikian apabila sekolah menciptakan lingkungan kerja yang nyaman dan menyenangkan dalam arti hubungan yang baik antara pegawai dan pimpinan serta menjaga kesehatan, keamanan diruang kerja pegawai.

Disiplin adalah ketaatan terhadap peraturan dan norma kehidupan bersmasyarakat, berbangsa dan bernegara yang dilaksanakan secara sadar dan ikhlas lahir batin sehingga timbul rasa malu dan taat karena sanksi. Dengan kata lain displin itu adalah mentaati peraturan yang telah ditentukan.

Disiplin disatu sisi merupakan sikap hidup dan perilaku yang mencerminkan tanggung jawab terhdap kehidupan tanpa paksaan dari luar.Sikap dan perilaku ini dianut berdasarkan keyakinan bahwa hal itu dianggap benar dan bahwa hal itu bermanfaat bagi diri sendiri maupun untuk kepentingan masyarakat. Disisi lain disiplin merupakan alat untuk menciptakan perilaku dan tata kehidupan manusia sebagai pribadi maupun sebagai kelompok dan masyarakat.

Faktor-faktor yang mempengaruhi Disiplin Kerja
Dalam pelaksanaan disiplin kerja, disiplin yang paling baik adalah disiplin diri. Kecenderungan orang normal adalah melakukan apa yang menjadi kewajibannya dan menempati aturan permainan, Organisasi atau perusahaan yang baik harus berupaya menciptakan peraturan atau tata tertib yang akan menjadi ramburambu yang harus dipenuhi oleh seluruh karyawan dalam organisasi. Peraturan-peraturan yang akan berkaitan dengan disiplin itu antara lain :

I. Peraturan jam masuk, pulang, dan jam istrahat

2. Peraturan dasar tentang berpakaian, dan bertingkah laku dalam pekerjan

3. Peraturan cara-cara melakukan pekerjaan dan berhubungan dengan unit kerja lain

4. Peraturan tentang apayang boleh dan apa yang tidak boleh dilakukan oleh pegawai selama dalam organisasi dan sebagainya. (Singodimedjo, 2000).

Parasuraman (Hutasoit, 20II : 66) kualitas pelayanan adalah perbedaan antara pelayanan yang diharapkan dengan pelayanan yang diterima. Sedangkan menurut Ibrahim (Hardiansyah, 201 I:40) kualitas pelayanan publik merupakan suatu kondisi dinamis yang berhubungan dengan produk, jasa, manusia, proses dan lingkungan dimana penilaian kualitasnya ditentukan pada saat terjadinya pemberian pelayanan tersebut.

Norman (Hardiansyah, 2011 : 35 ) mengatakan bahwa apabila kita ingin sukses memberikan kualitas pelayanan, kita harus memahami terlebih dahulu karakteristik tentang pelayanan sebagai berikut:

I. Pelayanan sifatnya tidak dapat diraba, pelayanan sangat berlawanan sifatnya dengan barang jadi.

2. Pelayanan itu kenyataanya terdiri dari tindakan nyata dan merupakan pengaruh yang sifatnya adalah tindakan sosial.

3. Produksi dan konsumsi dari pelayanan tidak dapat dipisahkan secara nyata, karena pada umumnya kejadian bersamaan dan terjadi di tempat yang sama. 


\section{METODOLOGI}

Dalam Penelitian ini menggunakan pendekatan kuantitatif dengan teknik observasi, dan kuisioner (angket). Sedangkan teknik analisis data yang digunakan dalam penilitian ini yaitu menggunakan anilisis korelasi product moment. Jenis penelitian ini bermaksud untuk menguji hipotesis dengan membenarkan dugaan yang telah dirumuskan dan dapat mendukung teori. Jenis penelitian yang digunakan metode kuantitatif adalah metode yang berdasarkan pada data penelitian berupa angka-angka dan analisis menggunakan statistik. Analisis statistik digunakan untuk mengetahui pengaruh antara Disiplin Guru Terhadap Kualitas Kerja di SMAN I Seruyan Tengah Kabupaten Seruyan.

\section{HASIL DAN PEMBAHASAN}

\section{Disiplin Kerja (variabel X)}

Adapun disiplin guru pegawai SMA Negeri I Seruyan Tengah di Kabupaten Seruyan dapat dilihat dari beberapa indikator berdasarkan teori (Hasibuan 2005 : 194-198) :Tujuan dan kemampuan, Teladan pemimpin, Balas Jasa, Keadilan, Waskat, Sanksi Hukum, Ketegasan, Hubungan Kemanusiaan.

a) Tujuan dan Kemampuan

Tujuan dan kemampuan ikut mempengaruhi tingkat kemampuan pegawai. Tujuan yang akan dicapai harus jelas dan ditetapkan secara ideal serta cukup menantang bagi kemampuan pegawai. Bagi para guru SMA Negeri I Seruyan Tengah di Kabupaten Seruyan sendiri tujuan dan kemampuan yang dimiliki sudah sangat baik, ini diperkuat dengan melihat hasil koesioner yang dibagikan berdasarkan pernyataan kejelasan tugas dan kesesuaian pekerjaan yang diterima, pada tabel 4.1 responden menjawab $100,00 \%$ mendapatkan tugas yang jelas, dan untuk pernyataan kesesuaian pekerjaan 89,04\% responden menjawab bekerja yang sesuai dengan keahliannya, dari hasil ini dapat dilihat bahwa para guru SMA
Negeri I Seruyan Tengah di Kabupaten Seruyan sudah mendapatkan tugas yang jelas dan mendapatkan pekerjaan yang sesuai dengan yang diharapkan. Bila dilihat dari indikator tujuan dan kemampuan, guru SMA Negeri I Seruyan Tengah di Kabupaten Seruyan telah melakukan yang sesuai dengan teori disiplin yang dikemukakan.

b) Teladan Pemimpin

Teladan pimpinan sangat berperan dalam menentukan kedisiplinan pegawai karena pimpinan dijadikan teladan dan panutan oleh para bawahannya.Pemimpin harus memberikan contoh dan teladan yang baik, ini seharusnya tidak cukup sulit untuk dilakukan seorang pemimpin, terlebih lagi bila itu sudah menjadi kebiasaan. Seorang pemimpin harus berhati-hati dalam memimpin, salah satu cara yang paling tepat dilakukan seorang pemimpin dalam memimpin bawahannyaa adalah sebisa mungkin menghindari kebiasaan buruk. Pimpinan di SMA Negeri I Seruyan Tengah di Kabupaten Seruyan masih belum memberikan teladan dan contoh yang baik bagi para bawahannya, berdasarkan hasil yang ditemukan pada tabel $4.3,37 \%$ responden menyatakan pemimpin masih sering datang terlambat ke kantor, dan ini membuat guru lain menjadi ikut datang terlambat, hal ini mungkin sering terjadi karena para guru menganggap datang terlambat merupakan hal yang biasa, dikarenakan pimpinan jarang, bahkan sering datang terlambat daripada pegawai lainnya. Dalam hal tanggung jawab pimpinan SMA Negeri I Seruyan Tengah di Kabupaten Seruyan sudah cukup baik memberikan teladan bagi bawahannya dalam memberikan arahan/bimbingan dalam bekerja ini terlihat dari setiap kali bawahannya mendapatkan tugas yang tidak jelas, pimpinan menjelaskan cara mengerjakan yang baik dan sesuai dengan ketentuan, hal ini diperkuat dengan hasil dari tabel 4.2 yang menyatakan $83,6 \%$ responden 
setuju bila pimpinan memberikan contoh perilaku yang baik. Atas arahan dan bimbingan dari pimpinan, guru dapat mengerjakan pekerjaan dengan maksimal dan sesuai dengan apa yang diharapkan oeh organisasi. Atas dasar inilah pimpinan sudah melaksanakan tanggung jawabnya sebagai pimpinan dan memberikan teladan yang cukup baik, namun ada beberapa yang harus diperbaiki oleh pimpinan dalam hal disiplin waktu terutama datang dan pulang bekerja, sehingga guru lainpun tidak ikut terlambat dan menyebabkan berkurangnya waktu kerja.

c) Balas Jasa

Balas jasa adalah imbalan yang diberikan kepada seseorang atas jerih parah payah yang telah disumbangkannya, imbalan akan jasa yang telah diterima akan memuaskan apabila dapat memenuhi kebutuhan hidup baik untuk memenuhi kebutuhan pegawai itu sendiri maupun kebutuhan keluarga. Balas jasa dapat diberikan dalam berbagai macam benutk misalnya dalam bentuk pemberian gaji atau upah,,tunjangan, uang kelebihan jam, uang makan, uang transport, uang penganti sewa rumah, pakaian dinas, rumah dinas dan dalam bentuk lain yang dinikmati oleh pegawai.

Balas jasa (gaji dan kesekahteraan) ikut mempengaruhi kedisplinan pegawai karena balas jasa akan memberikan kepuasan dan kecintaan terhadap organisasi/pekerjaannya. Di SMAN I Seruyan tengah guru pun mengharapkan imbalan yang sesuai dengan apa yang dikerjaannya dan apa yang menjadi tanggung jawabnya. Namun dari hasil yang ditemukan dilapangan, terlihat bahwa sebagian guru masih merasakan imbalan yang belum sesuai dengan tanggung jawab yang diberikan, ini dapat dilihat dari tabel 4.5 menyatakan bahwa 28,3 \% responden menyatakan kurang setuju, yang berarti mereka merasa imbalan yang diterima belum sesuai dengan yang diharapkan. Para guru pun sebagian besar juga tidak menerima tunjangan dari organisasi, ini terlihat dari tabel 4.6 yang menyatakan bahwa $38,7 \%$ responden tidak menerima tunjangan dari organisasi. Akibat kurang adanya perhatian dari organisasi mengenai gaji yang sesuai dengan ketentuan berlaku dan tidak adanya tunjangan bagi para pegawai ini bisa mempengaruhi disiplin kerja dalam bekerja, hal ini dikarenakan guru merasa apa yang diterima dan diharapkan dalam bekerja tidak sesuai dengan apa yang diharapkan.

d) Keadilan

Keadilan ikut mendorong terwujudnya kedisiplinan, karena ego dan sifat manusia yang selalu merasa dirinya penting dan minta diperhatikan sama dengan manusia lainnya, dalam suatu organisasi keadilan sangat diharapkan oleh seluruh pegawai, ini dilakukan agar tidak ada pegawai yang merasa pilih kasih dari seorang pimpinan kepada yang lain, di SMAN I Seruyan Tengah guru pun mengharapkan adanya keadilan dalam pemberian penghargaan, penghargaan ini didapat atas prestasi yang dihasilkan dalam organisasi, dari hasil temuan dilapangan terlihat ada tabel 4.7, bahwa belum adanya penghargaan dari organisasi atas hasil kerja guru yang memuaskan, ini terlihat dari $29,4 \%$ responden menjawab bahwa tidak adanya penghargaan dari pimpinan atas hasil kerja yang baik. Untuk menilai keadilan di SMAN I Seruyan Tengah ini dilakukan juga dengan melakukan penilaian atas pemberian hukum bagi guru, dari hasil temuan dilapangan pada tabel 4.8 didapat $22,6 \%$ responden kurang setuju pimpinan memberikan sanksi yang sama atas pelanggaran yang dilakukan berbeda oleh yang lain, namun sebagian guru merasa cukup adil atas sanksi yang diberikan oleh pimpinan atas pelanggaran yang dilakukan sejenis oleh para guru, dari hasil temuan dilapangan diatas dari koesioner penghargaan dan hukuman memperlihatkan keadilan yang diberikan masih belom sepenuhnya 
baik, karena terkadang keadilan yang diharapkan tidak dilakukan sesuai ketentuan yang berlaku.

e) Waskat

$$
\begin{gathered}
\text { Waskat ialah tindakan nyata dan efektif } \\
\text { untuk mencegah/mengetahui kesalahan, }
\end{gathered}
$$
membetulkan kesalahan, memelihara kedisiplinan, meningkatkan disiplin, meningkatkan prestasi kerja, mengaktifkan peranan atasan dan bawahan, menggali sistem-sistem kerja yang paling efektif, serta menciptakan sistem internal control yang terbaik dalam mendukung terwujudnya tujuan organisasi, guru dan peserta didik di SMAN I Seruyan Tengah dapat dinilai seberapa besar waskat yang ada dalam organisasi dan yang dapat dirasakan oleh gurunya, dari hasil temuan dilapangan terlihat adanya tindakan langsung dilapangan oleh pimpinan, pada tabel 4.9 dapat terlihat 93,33\% responden merasakan pimpinan melakukan pengawasan secara langsung dan pada tabel 4.10 sebanyak $78,7 \%$ responden mengatakan bahwa pimpanan selalu memberikan motivasi kepada guru agar bekerja lebih baik setiap harinya. Dengan melihat hasil yang ditemukan dilapangan dapat dilihat bahwa waskat di SMAN I Seruyan Tengah sudah baik dan sesuai yang diharapkan, hal ini akan membuat disiplin guru dalam bekerja bisa dimaksimalkan dengan sebaik mungkin.

f) Sanksi Hukuman

Dengan sanksi hukum yang semakin berat pegawai akan semakin takut melanggar peraturanperaturan organisasi, sikap dan perilaku indisipliner pegawai akan berkurang. Berat ringannya sanksi hukum yang akan diterapkan ikut mempengaruhi baik/buruknya kedisiplinan pegawai. Sanksi hukum harus dipertimbangkan secara logis, masuk akal dan dikonfirmasikan secara jelas kepada semua pegawai. Sanksi hukum seharusnya tidak terlalu ringan, namun juga tidak terlalu berat agar dapat tetap mendidik pegawai untuk mengubah perilaku. Untuk melakukan penilaian terhadap seberapa besar disiplin guru di SMAN I Seruyan Tengah dilakukan dengan menghitung seberapa besar hasil kuesioner yang didapat atas pernyataan yang diberikan, dari hasil yang didapat dilapangan terlihat dari tabel 4. I I,didapat 93,2\% responden menyatakan bahwa guru menerima sanksi secara langsung apabila telah melakukan pelanggaran, dan pada tabel 4.12 terlihat $57,5 \%$ responden menjawab guru mendapatkan sanksi secara tertulis, dari hasil yang ditemukan dilapangangan bahwa sanksi hukuman di SMAN I Seruyan Tengah sudah baik sehingga pelanggaran yang dilakukan akan tidak diulangi kembali, karena sanksi yang diberikan langsung dan tertulis terasa oleh guru, sehingga guru tidak akan melakukan pelanggaran lagi, hal ini akan membuat disiplin guru dalam bekerja bisa dimaksimalkan dengan sebaik mungkin.

g) Ketegasan

Pemimpin harus berani dan tegas, bertindak untuk menghukum setiap guru yang indisipliner sesuai dengan sanksi hukum yang telah ditetapkan, dengan demikian pimpinan akan mudah untuk disegani dan diakui kepemimpinannya oleh bawahan, di SMAN I Seruyan Tengah pimpinan dianggap tegas karena pimpinan berani memberikan sanksi yang sesuai dengan pelanggaran yang dilakukan guru dan guru mendapatkan tugas yang jelas dari pimpinan, hal ini dapat dlihat dari tabel 4.13 , sebanyak 95,2\% responden menyatakan sanksi yang diterima sesuai dengan pelanggaran yang dilakukan, ini memperlihatkan ketegasan pimpinan dalam memberikan sanksi kepada pelanggar dan langsung menentukan sanksinya. Guru di SMAN I Seruyan Tengah pun mengakui tugas yang diterima cukup dimengerti, ini dapat dilihat dari tabel 4.14 sebanyak 69,9\% mengungkapkan bahwa mereka mendapatkan tugas yang jelas dari pimpinan dan bagaimana cara mereka mengerjakannya. Hal ini 
menunjukan bahwa pimpinan SMAN I Seruyan Tengah sudah tegas dalam menentukan sanksi yang akan diberikan kepada guru yang melanggar sanksi, namun dilihat dari cara pemberian tugas kepada guru, pimpinan cukup baik. Dari indikator ketegasan dapat dikatakan pimpinan sudah tegas dalam memimpin pegawainya.

h) Hubungan Kemanusiaan

Hubungan kemanusiaan yang harmonis diantara guru ikut menciptakan kedisiplinan yang baik pada satu organisasi. Pimpinan harus berusaha menciptakan suasana hubungan kemanusian yang serasi serta mengikat, vertical maupun horizontal diantara semua pegawainya. Terciptanya human relationship (hubungan manusia) yang serasi akan mewujudkan lingkungan dan suasana kerja yang nyaman. Hubungan kemanusiaan antar guru tercipta berdasarkan kedisiplinan yang dimiliki setiap guru, untuk melihat disiplin guru berdasarkan indikator hubungan kemanusiaan di SMAN I Seruyan Tengah, dapat dilihat dari tabel 4.15 sebanyak $97,2 \%$ responden menyatakan guru membantu orang lain tanpa diminta, dan dari tabel 4.16 terlihat karyawan guru menolong guru lain yang memerlukan bantuan, ini diperkuat dengan hasil 100\% responden menyatakan kesadaran para guru untuk membantu orang lain dalam hubungan kemanusiaan ini sangat baik, hal itu dikarenakan adanya perhatian dari pimpinan itu sendiri untuk membuat suasana yang harmonis antar pegawai, sehingga pegawai pun memperdulikan pegawai lain.

\section{Kualitas Kerja (variabel $\mathbf{Y}$ )}

Kualitas Kerja adalah hasil dari suatu pekerjaan sesuai dengan apa yang diharapkan. Suatu perbandingan antara hasil keluaran dan masukan. Masukan sering dibatasi dengan tenaga kerja, sedangkan keluaran diukur dalam kesatuan fisik, bentuk, dan nilai. Kualitas pada dasarnya mencakup hasil yang selalu mempunyai pandangan bahwa hasil yang baik di hari lebih baik dari hari kemarin dan hari esok lebih baik dari hari ini. kualitas kerja adalah kemampan pegawai/karyawan dalam berproduksi dibandingkan dengan input yang digunakan, seorang pegawai/karyawan dapat dikatakan berkualitas apabila mampu menghasilkan sesuatu sesuai dengan diharapkan dalam waktu yang singkat atau tepat. Pengukuran kualitas kerja sebagai sarana untuk menganalisa dan mendorong hasil yang diberikaan. Manfaat lain adalah untuk menentukan target dan kegunaan, praktisnya sebagai standar, dalam pembayaran upah pegawai. Untuk melihat seberapa besar kualitas kerja SMAN I Seryan Tengah, yaitu: Tangibles (bukti fisik), Reliability (kehandalan), Responsiveness (ketanggapan), Assurance (jaminan dan kepastian), Empathy (empati).

a) Tangibles (bukti fisik),

Tangibel (bukti fisik) menunjukkan lokasi dalam eksistensinya kepada pihak eksternal. Dalam suatu organisasi penampilan dan kemampuan fisik adalah bukti nyata dari pelayana yang diberikan oleh pemberi jasa. Kondisi gedung dan peralatan merupakan bukti fisik nyata dari kemungkinan kualitas kerja yang berikan oleh guru SMAN I Seruyan Tengah, hal ini dimaksudkan agar tujuan yang ingin dicapai oleh organisasi dapat terwujud, pada SMAN I Seruyan Tengah Penampilan guru rapi dan bersih dapat dilihat pada tabel 4.17 yaitu $90,4 \%$ responden menyatakan Penampilan guru rapi dan bersih, ini menunjukkan bahwa guru SMAN I Seruyan Tengah mampu memberikan contoh yang baik, dan mengenai Peralatan, perlengkapan dan sarana yang memadai terlihat pada tabel 4.18 bahwa 97,2\% responden menyatakan bahwa Peralatan, perlengkapan dan sarana yang memadai, ini memperlihatkan bahwa bukti fisik di SMAN I Seruyan sudah baik dan akan membantu tujuan yang ingin dicapai secara bersama.

b) Reability

Reabilty (kehandalan) merupakan kemampuan guru dalam memberikan pelajaran dan pelayanan dengan baik. Dalam meningkatkan Hasil yang Dicapai merupakan salah satu yang dapat dirasakan baik oleh 
yang mengerjakan maupun yang menikmati hasil pekerjaan tersebut. Begitupun kualitas dalam pemberian materi dengan handal dapat dilihat dari data yang ditemukan dilapangan, pada tabel $4.1978,8 \%$ responden mengatakan bahwa guru SMAN I Seruyan Tengah sudah memberikan materi dengan handal. Sedangkan tabel 4.20 , responden menyatakan $82,2 \%$ pemberian materi kepada peserta didik dengan jelas, ini dikarenakan setiap guru memiliki tupoksi masingmasing dari organisasi, sehingga guru lebih mudah dalam pemberian materi.

c) Responsiveness (tanggapan)

Responsiveness (tanggapan) merupakan sikap individu untuk bekerja sama dengan disiplin dan rasa tanggung jawab terhadap pekerjaanya. Responsiveness (tanggapan) dalam bekerja dalam suatu organisasi akan tumbuh apabila pekerjaan yang diterima sesuai dengan apa yang diharapkan dan sesuai dengan kemampuan yang dimiliki, lingkungan kerja pun sangat mempengaruhi Responsiveness (tanggapan) dalam bekerja. Kesiapan guru dalam memberikan motivasi kepada peserta didik di SMAN I Seruyan Tengah, ini terlihat pada tabel 4.21\%, 89,7 responden menyatakan Kesiapan guru dalam memberikan motivasi kepada peserta didik, hal ini memperlihatkan adanya responsiveness dalam bekerja, dan kemauan guru untuk membantu peserta didik, ini terlihat pada tabel 4.22 dengan persentase $67,1 \%$ responden menyatakan Kemauan guru untuk membantu peserta didik, hal ini memperlihatkan guru memiliki rasa tanggap yang tinggi.

d) Assurance (jaminan dan kepastian)

jaminan dan kepastian merupakan dimensi kualitas yang berhubungan dengan kemampuan organisasi. Setiap individu mempunyai kekuatan yang bersumber dari dirinya, namun banyak orang yang merasa tidak mempunyai kemampuan apa-apa, merasa dirinya tidak berguna dan tidak mampu mencapai aktualisasi diri. Dari hasil yang diperoleh dari lapangan, di SMAN I Seruyan Tengah Guru memiliki citra yang baik dengan peserta didik ini terlihat pada tabel 4.23 yang mengatakan 59,6\% responden menyatakan Guru memiliki citra yang baik dengan peserta didik, dan pada tabel 4.24 memperlihatkan $72,6 \%$ responden mengatakan Guru memberi kenyaman di saat jam belajar mengajar. Hasil diatas memperlihatkan bahwa kualitas kerja di SMAN I Seruyan Tengah sudah baik,demi kebaikan diri sendiri maupun organisasi, hal ini dilakukan agar pekerjaan yang diterima bisa dikerjakan dengan baik tanpa terkendala oleh masalahmasalah yang tidak diinginkan dalam bekerja.

e) empaty

untuk menunjukkan sikap empaty, setiap guru hendaknya mengelola waktu dengan baik agar mudah dihubungi, sehingga peserta didik tidak menunggu lama saat pergantian jam pelajaran. Jadi menunjukkan sikap empaty bertujuan untuk memberikan hasil yang terbaik dan berguna bagi suatu organisasi dan diri sendiri. Suatu organisasi selalu menuntut guru untuk menghasilkan pekerjaan yang berkualitas sesuai dengan harapan. Pada SMAN I Seruyan Tengah tidak adanya perbedaan dalam status sosial, ini dapat dilihat pada tabel 4.25, 95,2\% responden menyatakan tidak adanya perbedaan dalam status sosial, serta pada tabel 4.26, 43,9\% responden menyatakan Guru selalu memberikan perhatian kepada peseta didik, hal ini memperlihatkan tidak adanya perbedaan dalam status sosial dalam memberikan pelajaran tetapi Guru terkadang tidak selalu memberikan perhatian kepada peseta didik.

\section{KESIMPULAN}

Berdasarkan hasil dari penilitian dan pembahasan, disiplin guru berpengaruh positif dan signifikan terhadap terhadap kualitas kerja guru SMAN I Seruyan Tengah kabupaten Seruyan,dimana indikator disiplin (x) yang terdiri dari Tujuan dan kemampuan, Teladan pemimpin, Balas jasa, Keadilan, Waskat (pengawasan Melekat), Sanksi hukum, Ketegasan, Hubungan kemanusiaan berpengaruh positif dan signifikan terhadap terhadap kualitas kerja yang terdiri dari 
Tangibles (bukti fisik), Reliability (kehandalan), Responsiveness (ketanggapan), Assurance (jaminan dan kepastian), Empathy (empati).

Maka penulis memberikan saran kepada pegawai SMAN I Seruyan Tengah yakni perlu adanya peningkatan pengawasan pimpinan dan perhatian kepada seluruh guru dalam melaksanakan tugasnya. Serta, adanya reward dan punishment dari pimpinan kepada guru agar tetap berkualitas dalam melaksanakan tugas.

\section{REFERENSI}

Bulkani, B. 2014. Perbedaan Kemampuan Menulis Karya IImiah Mahasiswa PGSD UM Palangkaraya Ditinjau dari Pemberian Resitasi dan Jenis Kelamin. Anterior Jurnal, I3(2), 173-180.

Dwiyanto, Agus. 2006. Mewujudkan Good Governance melalui Pelayanan Publik. Yogyakarta: Gadjah Mada University Press.

Dharma, dan Dahriel, Rycko. 2013. Manajemen Sumber Daya Manusia Di Sektor Jasa Tenaga Kerja. Penerbit pustaka pelajar.

Hasibuan, Malayu. S.P. 2005. Manajemen Sumber Daya Manusia. Jakarta : PT. Bumi Aksara.

Hardyansah. 20II. Kualitas Pelayanan Publik. Yogyakarta: Gava Media.

Kartono, Kartini. 2008. Pemimpin dan Kepemimpinan. Jakarta. PT Raja Grafindo Persada.

Mankunegara, A.A. Anwar. Prabu. 20II Manajemen Sumber Daya Manusia Perusahan. Bandung : PT Remaja Rosdakarya.

Nasucha, Chaizi. 2004. Reformasi Administrasi Publik Teori dan Praktek. Jakarta: PT. Grasindo Anggota Ikapi.
Nurmandi, Achmad. 2010. Manajemen Pelayanan Publik. Yogyakarta: PT. Sinergi Visi utama

Putra, A. R. B. 2015. Peran Guru Bimbingan Konseling Mengatasi Kenakalan Remaja di Sekolah. Pedagogik: Jurnal Pendidikan, I0(I), 32-39.

Silalahi, Ulber. Asas-Asas Manajemen. 20II. Bandung : PT Refika Aditama.

Sonedi, S. 2016. Hubungan Kepemimpinan Kepala Sekolah dan Sikap Guru Terhadap Pekerjaan dengan Kompetensi Profesional Guru. Anterior Jurnal, 16(1), 14-27.

Sonedi, S. 2016. Pengaruh Kepemimpinan Kepala Sekolah, Iklim Organisasi Terhadap Kepuasan Kerja Guru. Pedagogik: Jurnal Pendidikan, I I(2), |34-145.

Sugandi, Yogi Suprayogi. 201I. Administrasi Publik Konsep dan Perkembangan Ilmu di Indonesia. Bandung: Graha IImu.

Suniati, S. 2014. Hubungan Gaya Kepemimpinan Kepala Sekolah Dengan Efektivitas Sekolah Menengah Atas Negeri Se-Kota Palangka Raya. Anterior Jurnal, I4(I), I 10-1 I8.

Sutrisno, Edy. 2009. Manajemen Sumber Daya Manusia. Jakarta : Kencana Prenada Media GroupSurya

Tangkilisan, Hassel Nogi S, 2005. Manajemen Publik. Jakarta; Grasindo 